\title{
PENGARUH MODEL PEMBELAJARAN SNOWBALL THROWING TERHADAP MINAT BELAJAR GEOGRAFI KELAS XI IIS SMA NEGERI 1 TUMPANG KABUPATEN MALANG
}

\author{
Endang Wijaya Tri Pamungkas ${ }^{1}$, Sudarno Herlambang ${ }^{2}$, Juarti $^{3}$ \\ Email: endangwijayatripamungkas09@gmail.com, \\ sudarno.herlambang.fis@um.ac.id, juarti.fis@um.ac.id
}

\begin{abstract}
This study aims to describe the influence of the Snowball Throwing learning model toward the learning interest of student of State Senior High School of 1 Tumpang in the subject of geography. This research is a quasy experiment with pretest-posttest only control group design in the form of student interest in the subject of geography and snowball throwing learning model. The sample of this research was taken from class of XI IIS 1 as the controlled class of 26 students and the class of XI IIS 2 as the experimental class of the 27 students. The instrument of this research a questionnaire of geographic learning interest that is consisting of a questionnaire of pre test and post test. Based on result of the research that was any different interest between the experiment class which using a snowball throwing learning model and control class which using lecture and debriefing with sig (2-tailed) 0,000 < 0,05, so H0 is defused and H1 is accepted which mean that any difference of geographical learning interest control class and experiment class. The average score of gain score on experiment class is higher than the control class, namely $16,59>3,08$, it indicates there is effect of snowball throwing learning model to the geographical learning interest of student XI IIS at State Senior High School of 1 Tumpang.
\end{abstract}

Key Word: Snowball Throwing, Learning Interest.

\section{PENDAHULUAN}

Model pembelajaran Snowball Throwing adalah pembelajaran yang dikemas dalam suatu permainan menarik yaitu saling melempar bola di kertas yang berisi pertanyaan. Pada model pembelajaran ini ditekankan pada kemampuan siswa untuk merumuskan suatu pertanyaan tentang materi yang telah dijelaskan oleh guru. Pembelajaran yang dikemas dalam permainan ini membutuhkan suatu kemampuan sederhana, sehingga dapat dilakukan oleh seluruh siswa dalam bekerja sama dengan siswa lain maupun kemampuan

\footnotetext{
${ }^{1}$ Mahasiswa Jurusan Geografi FIS UM

${ }^{2}$ Dosen Jurusan Geografi FIS UM

${ }^{3}$ Dosen Jurusan Geografi FIS UM
}

individunya dapat diukur dengan menggunakan model pembelajaran ini.

Kegiatan melempar bola pertanyaan ini akan membuat kelompok menjadi dinamis, karena siswa tidak hanya berpikir, menulis, bertanya, atau berbicara. Pada pembelajaran Snowball Throwing ini, siswa juga melakukan aktivitas fisik, yaitu menggulung kertas dan melemparkannya pada siswa lain. Aktivitas fisik tersebut akan membuat setiap anggota kelompok akan mempersiapkan diri karena pada giliranya mereka harus menjawab pertanyaan dari siswa lain yang terdapat 
102

Endang Wijaya Tri Pamungkas, Sudarno Herlambang, Juarti. Pengaruh Model Pembelajaran Snowball Throwing Terhadap Minat Belajar Geografi Kelas XI IIS SMA Negeri 1 Tumpang

Kabupaten Malang

dalam bola kertas. Pada kegiatan pembelajaran yang menggu-nakan model pembelajaran Snowball Throwing ini strategi memperoleh dan pendalaman pengetahuan lebih diutamakan dibandingkan seberapa banyak siswa memperoleh dan mengingat pengetahuan tersebut.

Pada pembelajaran Snowball Throwing guru berusaha memberikan kesempatan kepada siswa untuk mengembangkan keterampilan menyimpulkan isi berita atau informasi yang mereka peroleh dalam konteks nyata dan situasi yang kompleks. Guru juga memberikan pengalaman kepada siswa melalui pembelajaran terpadu dengan menggunakan proses yang saling berkaitan dalam situasi dan konteks komunikasi alamiah, baik sosial, sains, hitungan dan lingkungan pergaulan.

Menurut Hamdayana (2014) pembelajaran dengan menggunakan model Snowball Throwing, termuat di dalam prinsip pendekatan kooperatif yang didasarkan pada lima prinsip, yaitu prinsip belajar siswa aktif (student active learning), belajar kerjasama (cooperative learning), pembelajaran partisipatorik, mengajar reaktif (reactive teaching), dan pembelajaran yang menyenangkan (joyfull learning).

Pembelajaran dengan menggunakan model Snowball Throwing menggunakan tiga penerapan pembelajaran, antara lain pengetahuan dibangun sedikit demi sedikit yang hasilnya diperluas melalui konteks yang terbatas melalui pengalaman nyata (construktivism), pengetahuan dan keterampilan yang diperoleh siswa diharapkan bukan hasil mengingat seperangkat fakta-fakta tetapi hasil dari menemukan sendiri (inquiry), pengetahuan yang dimiliki oleh seseorang, selalu bermula dari bertanya (questioning), dari bertanya maka siswa dapat menggali informasi, mengkonfirmasikan apa yang diketahui, dan mengarahkan perhatian pada aspek yang belum diketahui. Strategi memperoleh dan pendalaman pengetahuan di dalam model pembelajaran Snowball Throwing lebih diutamakan dibandingkan seberapa banyak siswa memperoleh dan mengingat pengetahuan tersebut.

Menurut Hamdayana (2014) kelebihan model pembelajaran Snowball Throwing ini adalah (1) suasana pembelajaran menjadi menyenangkan karena siswa seperti bermain dengan melempar bola kertas kepada siswa lain, (2) siswa mendapatkan kesempatan untuk mengembangkan kemampuan berpikir karena diberi kesempatan untuk membuat pertanyaan, (3) membuat siswa siap dengan berbagai kemungkinan karena siswa tidak tahu bentuk soal yang dibuat temannya seperti apa, (4) siswa terlibat aktif dalam pembelajaran, (5) guru lebih efisien dalam membuat media karena siswa terjun langsung dalam praktek, (6) pembelajaran menjadi lebih efektif, (7) aspek kognitif, afektif dan psikomotor dapat tercapai.

Tahap-tahap dalam model pembelajaran Snowball Throwing ini meliputi: penjelasan materi dari guru, pembentukan kelompok dan penjelasan masing-masing ketua kelompok kepada anggota kelompoknya, diskusi kelompok mengenai pertanyaan yang akan ditulis, pelemparan bola pertanyaan kepada kelompok lain, 
menjawab pertanyaan dari kelompok lain, dan evaluasi.

Penggunaan model pembelajaran yang tepat akan berpengaruh terhadap minat belajar siswa. Hal tersebut sesua dengan hasil penelitian yang telah dilakukan oleh Amilia pada tahun 2015 mengungkapkan bahwa model pembelajaran Snowball Throwing berpengaruh positif terhadap minat belajar siswa. Minat mengacu pada keterlibatan diri yang disukai dan dikehendaki pada sebuah aktivitas (Schunk, dkk, 2012:316). Siswa yang memiliki minat tinggi terhadap suatu aktivitas maka secara tidak langsung akan terlibat aktif di dalam aktivitas tersebut. Hal ini juga berlaku bagi proses pembelajaran Geografi di kelas. Jika minat belajar siswa tinggi maka akan mempengaruhi kemauan siswa untuk mempelajari serta mencari informasi lebih banyak lagi sehingga diharapkan lebih mengoptimalkan lagi potensi yang dimiliki oleh masing-masing siswa, dan secara langsung juga akan berpengaruh terhadap hasil dan prestasi belajar siswa.

Slameto (2010) menyebutkan bahwa faktor yang mempengaruhi minat dibedakan menjadi faktor intern dan ekstern. Faktor intern atau faktor yang berasal dari dalam diri siswa memiliki peranan yang cukup besar dalam mempengaruhi minat siswa yang meliputi faktor jasmaniah, psikologis, kelelahan. Faktor ekstern ini adalah kondisi-kondisi yang mempengaruhi minat siswa yang berasal dari luar diri siswa yang meliputi faktor keluarga, sekolah, dan masyarakat. Tentu saja faktor sekolah memiliki peran yang penting dalam menciptakan minat belajar siswa. Faktor ekstern yang berasal dari sekolah ini meliputi metode dan model mengajar guru, kurikulum yang digunakan, interaksi guru dengan siswa, interaksi siswa dengan siswa, disiplin sekolah, alat pelajaran, waktu sekolah, standar pelajaran di atas ukuran, keadaan gedung, metode belajar, dan tugas rumah. Berdasarkan pernyataan tersebut jelas bahwa model pembelajaran merupakan salah satu faktor penting yang mempengaruhi minat belajar siswa.

Penelitian ini bertujuan untuk mengetahui pengaruh model pembelajaran Snowball Throwing terhadap minat belajar geografi siswa kelas XI IIS SMA sehingga dapat menjadi salah satu referensi pembelajaran yang digunakan untuk menumbuhkan minat belajar pada mata pelajaran geografi siswa SMA.

\section{METODE}

Penelitian ini menggunakan metode eksperimen semu (quasy experiment) dengan pre test-post test only group design. Disebut eksperimen semu karena subjek Penelitian ini melibatkan dua kelompok yang diteliti yaitu, kelompok eksperimen yang menggunakan model Snowball Throwing dalam proses pembelajaran dan kelompok kontrol yang menggunakan metode ceramah dan tanya jawab. Tujuan penelitian ini untuk mengetahui bagaimana pengaruh penggunaan model pembelajaran Snowball Throwing terhadap minat belajar geografi siswa kelas XI IIS. Sehingga pada kedua kelompok tersebut akan diberikan tes minat belajar yang diberikan dua kali yaitu pre testdan post test. Subjek dalam penelitian ini adalah siswa kelas XI IIS 2 sebagai kelas eksperimen dan kelas XI IIS 1 sebagai kelas kontrol. 
104

Endang Wijaya Tri Pamungkas, Sudarno Herlambang, Juarti. Pengaruh Model Pembelajaran Snowball Throwing Terhadap Minat Belajar Geografi Kelas XI IIS SMA Negeri 1 Tumpang

Kabupaten Malang

Instrumen penelitian yang digunakan adalah angket minat belajar yang terdiri dari 40 item pertanyaan dan pernyataan yang mengacu pada indikator tentang minat yang terdiri dari kesukaan, ketertarian, perhatian, dan keterlibatan (Sudaryono, 2013). Angket diberikan di awal dan di akhir pembelajaran untuk kelas eksperimen maupun kelas kontrol.

Angket yang digunakan berisi pertanyaan dan pernyataan menggunakan Skala Likert. Sebelum angket diberikan kepada siswa terlebih dahulu dilakukan uji coba untuk mengetahui validitas dan reliabilitas item pertanyaan. Angket diberikan sebelum dan setelah perlakuan. Jenis data yang digunakan dalam penelitian ini adalah data kuantitatif berupa skor minat belajar. Sebelum dilakukan uji hipotesis terlebih dahulu data yang te- lah diperoleh dilakukan uji beda rata-rata (mean), uji prasyarat (normalitas dan homogenitas) dan uji hipotesis untuk mengetahui pengaruh model pembelajaran Snowball Throwing terhadap minat belajar siswa. Uji prasyarat dilakukan untuk menentukan jenis uji hipotesis harus menggunakan statistik parametrik atau statistik non parametrik. Analisis data dilakukan dengan bantuan SPSS 21 for Windows.

\section{HASIL}

Hasil tanggapan siswa terhadap kesukaan, ketertarikan, perhatian, dan keterlibatan pada mata pelajaran geografi dapat dilihat pada Tabel 1 berikut.

Tabel 1.1 Hasil Rata-Rata Minat Belajar Geografi Siswa

\begin{tabular}{lllllll}
\hline Indikator & Pre Test & \multicolumn{3}{c}{ Post Test } & \multicolumn{3}{c}{ Gain Score } \\
\cline { 2 - 7 } & Kontrol & Eksperimen & Kontrol & Eksperimen & Kontrol & Eksperimen \\
\hline Kesukaan & 0,688 & 0,666 & 0,706 & 0,759 & 0,018 & 0,094 \\
\hline Ketertarikan & 0,753 & 0,720 & 0,764 & 0,800 & 0,010 & 0,080 \\
\hline Perhatian & 0,691 & 0,634 & 0,686 & 0,722 & $-0,005$ & 0,088 \\
\hline Keterlibatan & 0,627 & 0,576 & 0,669 & 0,702 & 0,042 & 0,126 \\
\hline
\end{tabular}

Berdasarkan Tabel 1.1 di atas menunjukkan hasil rata-rata indikator minat belajar siswa antara kelas kontrol dan kelas eksperimen. Rata-rata pre test pada kelas kontrol lebih tinggi daripada kelas eksperimen, tetapi setelah diberikan perlakuan dan diberikan diperoleh hasil post test kelas eksperimen lebih tinggi daripada kelas kontrol. Kenaikan rata-rata tanggapan siswa terhadap indikator minat belajar tersebut menunjukkan bahwa penggunaan model pembelajaran Snowball Throwing berpengaruh terhadap minat belajar siswa. Selisih rata-rata antara pre test dan post test atau gain score juga menunjukkan bahwa rata-rata kelas eksperimen lebih tinggi daripada kelas kontrol.

Selisih rata-rata tertinggi antara kedua kelas berada pada indikator keterlibatan yaitu sebesar 0,042 pada kelas kontrol dan 0,126 pada kelas eksperimen. 
Selisih rata-rata terendah pada kelas eksperimen berada pada indikator ketertarikan yaitu sebesar 0,080 , sedangkan selisih terendah pada kelas kontrol berada pada indikator perhatian yaitu sebsar -0,005. Indikator ketertarikan pada kelas kontrol memliki selisih ratarata sebesar 0,010, sementara itu selisish rata-rata indikator perhatian pada kelas eksperimen sebesar 0,080. Indikator kesukaan memiliki selisih rata-rata yang berbeda pada masing-masing kelas yaitu 0,018 pada kelas kontrol dan 0,094 pada kelas eksperimen. Dari selisih rata-rata perolehan tanggapan siswa terhadap indikator minat belajar tersebut menunjukkan bahwa rata-rata kelas eksperimen lebih tinggi daripada kelas kontrol.

Berdasarkan hasil uji hipotesis di atas dapat diketahui bahwa nilai Sig. (2tailed) adalah $0,00<0,05$. Hal ini berarti ada perbedaan minat belajar geografi siswa antara kelas kontrol dan kelas eksperimen. Pengujian hipotesis selain dilihat dari nilai signifikan juga dilihat dari rata-rata gain score kelas eksperimen dan kelas kontrol. Rata-rata gain score kelas eksperimen lebih tinggi daripada kelas kontrol yaitu 16,59> 3,08 maka dapat disimpulkan bahwa ada pengaruh model pembelajaran snowball throwing terhadap minat belajar geografi siswa.

\section{PEMBAHASAN}

Pada penelitian ini minat belajar siswa dilihat dari beberapa indikator yaitu, kesukaan, ketertarikan, perhatian, dan keterlibatan siswa dalam pembelajaran (Sudaryono, dkk:2013). Hal tersebut diperkuat oleh pernyataan Slameto (2010) yang mengatakan bahwa adanya ket- ertarikan dan kesenangan dapat digunakan untuk meningkatkan minat belajar siswa. Siswa yang memiliki minat yang tinggi terhadap suatu aktivitas maka seara tidak langsung akan terlibat aktif dalam aktivitas tersebut. Hal ini juga berlaku pada proses pemeblajaran geografi di kelas. Jika minat siswa tinggi maka akan mempengaruhi kemauan siswa untuk mempelajari serta mencari informasi yang lebih banyak lagi tentang materi yang dipelajari, sehingga diharapkan lebih mengoptimalkan lagi potensi yang dimiliki oleh masing-masing siswa.

Empat indikator yang telah disebutkan sebelumnya saling terkait antara satu sama lain. Pada penelitian ini indikator kesukaan siswa dapat dilihat ketika siswa menikmati proses pembelajaran yang sedang berlangsung. Selain dapat tumbuh dari dalam diri siswa itu sendiri kesukaan juga dipengaruhi oleh dorongan yang berasal dari luar siswa seperti motivasi yang diberikan oleh guru. Kemampuan guru untuk memotivasi siswa dalam proses pembelajaran dapat dilakukan dengan menerapkan model pembelajaran yang sesuai. Senang atau suka terhadap suatu mata pembelajaran membuat siswa untuk tidak enggan lagi mengajukan pertanyaan atas apa yang belum mereka pahami. Jadi model pembelajaran Snowball Throwing ini mampu mengajak siswa untuk menggali rasa ingin tahunya.

Data yang didapat dari hasil penelitian menunjukkan bahwa perbedaan kesukaan antara kelas eksperimen yang menggunakan model pembelajaran Snowball Throwing mengalami peningkatan rata-rata sebesar 0,094 sedangkan pada kelas kontrol yang menggunakan metode ceramah dan tanya jawab dalam 
106

Endang Wijaya Tri Pamungkas, Sudarno Herlambang, Juarti. Pengaruh Model Pembelajaran Snowball Throwing Terhadap Minat Belajar Geografi Kelas XI IIS SMA Negeri 1 Tumpang Kabupaten Malang

proses pembelajaran mengalami peningkatan rata-rata sebesar 0,018 . Peningkatan indikator kesukaan di kelas eksperimen yang lebih besar daripada kelas ekperimen tentunya dipengaruhi oleh beberapa faktor. Salah satunya adalah siswa merasa jenuh ketika guru menggunakan metode ceramah sehingga siswa mendengarkannya sambil melakukan aktivitas lainnya seperti bermain gadget bahkan tidur. Hal tersebut didukung oleh pendapat Purwanto (2013) bahwa salah satu keterbatasan metode ceramah adalah guru hampir tidak memiliki kesempatan untuk mengontrol apakah siswa telah memahami materi yang diceramahkan. Hal tersebut membuktikan bahwa kegiatan diskusi dalam pembelajaran Snowball Throwing mampu mempengaruhi kesukaan siswa terhadap materi pelajaran.

Indikator yang kedua yaitu ketertarikan. Minat belajar akan muncul jika siswa merasa tertarik terhadap berbagai hal yang dipelajarinya, atau siswa tersebut menyadari kaitan hal-hal yang dipelajari. Hal tersebut didukung oleh pendapat Gie (1998) bahwa "minat berarti sibuk, tertarik, atau terlibat sepenuhnya dengan sesuatu karena menyadari pentingnya kegiatan itu". Faktor yang mempengaruhi ketertarikan siswa ini tidak hanya berasal dari dalam diri siswa tetapi juga dari luar diri siswa, misalnya jenis materi dan cara guru menggunakan model pembelajaran di dalam kelas. Berdasarkan hasil penelitian terlihat bahwa peningkatan nilai ketertarikan kelas yang menggunakan model pembelajaran Snowball Throwing yaitu 0,080 berbeda dengan kelas yang menggunakan metode ceramah yang hanya mengalami kenaikan sebesar 0,010. Rata-rata tersebut menunjukkan bahwa kelas eksperimen memiliki nilai rata-rata yang lebih besar daripada kelas kontrol.

Indikator lain selain kesukaan dan ketertarikan yaitu perhatian. Pada indikator perhatian ini data dilihat bagaimana perhatian siswa dalam mengikuti proses pembelajaran yang sedang berlangsung. Perhatian akan muncul karena dorongan rasa ingin tahu yang tinggi. Rasa ingin tahu perlu mendapat rangsangan, sehingga siswa akan memberikan perhatian selama proses pembelajaran di kelas. Perhatian siswa ini dapat tumbuh salah satunya karena dorongan dari luar diri siswa seperti motivasi yang diberikan oleh guru. Kemampuan guru untuk menarik perhatian siswa mengenai materi yang disampaikan selama proses pembelajaran sangatlah penting. Data yang didapatkan berdasarkan hasil penelitian menunjukkan bahwa indikator perhatian di kelas eksperimen yang menggunakan model pembelajaran Snowball Throwing dalam proses pembelajarannya mengalami peningkatan sebesar 0,088 , sedangkan di kelas kontrol yang menggunakan metode ceramah justru mengalami penurunan perhatian siswa sebesar $-0,005$. Hal ini membuktikan bahwa model pembelajaran Snowball Throwing mampu meningkatkan perhatian siswa karena proses pembelajaran yang menarik dan menyenangkan.

Gie (1998) menyatakan bahwa "minat berarti sibuk, tertarik, atau terlibat sepenuhnya dengan sesuatu kegiatan karena menyadari pentingnya kegiatan itu". Keterlibatan siswa secara aktif dalam proses pembelajaran terjadi ketika siswa sudah menyukai, merasa tertarik dan 
menaruh perhatian yang besar ke dalam proses pembelajaran. Keterlibatan siswa dapat dilihat dari aktivitas siswa dalam kelompok serta tanya jawab siswa ketika diskusi maupun presentasi baik kepada siswa antar kelompok maupun kepada guru. Pada kelas eksperimen keterlibatan siswa meningkat sebesar 0,126 Di kelas kontrol yang proses pembelajarannya menggunakan metode ceramah dan tanya jawab keterlibatan siswa mengalami peningkatan sebesar 0,042. Peningkatan indikator keterlibatan siswa di kelas eksperimen yang jauh lebih tinggi daripada di kelas kontrol menunjukkan bahwa siswa di kelas eksperimen menaruh minat yang tinggi terahadap proses pembelajaran. Jadi terbukti bahwa penggunaan model pembelajaran Snowball Throwing berpengaruh terhadap minat belajar siswa.

Model pembelajaran Snowball Throwing berpengaruh terhadap minat belajar siswa karena proses pembelajaran yang menyenangkan. Pembelajaran yang menggunakan model Snowball Throwing dikemas dalam suatu permainan yang menarik yaitu saling melempar bola kertas yang sudah berisi pertanyaan. Pada model pembelajaran ini siswa ditekankan untuk merumuskan suatu pertanyaan yang berkaitan dengan materi yang dipelajari. Proses pembelajaran yang seperti ini akan membuat siswa terlibat aktif di dalamnya.

Pembelajaran dengan menggunakan model Snowball Throwing dapat menguji pemahaman siswa dalam menjawab pertanyaan dari siswa lain. Selain itu juga dapat membantu siswa untuk memahami konsep dengan baik melalui diskusi kelompok, karena siswa harus membuat pertanyaan untuk diberikan kepada ke- lompok lain. Dengan adanya diskusi kelompok tersebut maka akan menambah antusiasme dan ketekunan siswa dalam membuat maupun menjawab pertanyaan.

Hasil penelitian ini sejalan dengan penelitian yang telah dilakukan oleh Amalia (2015) yang menunjukkan bahwa penerapan model pembelajaran Snowball Throwing berpengaruh terhadap minat belajar siswa. Dalam penelitian tersebut membuktikan bahwa model pembelajaran Snowball Throwing mampu meningkatkan aktivitas siswa dalam proses pembelajaran. Dalam pembelajaran yang menggunakan model Snowball Throwing siswa berkesempatan mengajukan pertanyaan tanpa harus takut dan malu. Penelitian yang dilakukan oleh Ratih (2011) juga menyebutkan bahwa model pembelajaran Snowball Throwing mampu meningkatkan aktivitas dan hasil belajar IPS siswa.

Model pembelajaran Snowball Throwing menurut Hamdayana (2014) adalah suatu kegiatan yang membagi siswa ke dalam beberapa kelompok, yang nantinya masing-masing anggota kelompok membuat pertanyaan pada selembar kertas dan membentuknya seperti bola, kemudian bola tersebut dilempar kepada kelompok lain selama durasi yang ditentukan, kemudian masingmasing kelompok menjawab pertanyaan dari bola yang diperolehnya. Dalam kegiatan ini guru memberikan kesempatan kepada siswa untuk mengembangkan keterampilan menyimpulkan isi berita atau informasi yang siswa peroleh dalam konteks nyata dan situasi yang kompleks.

Berdasarkan penelitian yang telah dilakukan di kelas eksperimen mennjuk- 
108

Endang Wijaya Tri Pamungkas, Sudarno Herlambang, Juarti. Pengaruh Model Pembelajaran Snowball Throwing Terhadap Minat Belajar Geografi Kelas XI IIS SMA Negeri 1 Tumpang

Kabupaten Malang

kan bahwa model pembelajaran Snowball Throwing ini memiliki kelebihan. Kelebihan tersebut adalah (1) diskusi kelompok dan interaksi antar siswa dari kelompok yang berbeda memungkinkan terjadinya saling tukar pengetahuan dan pengalaman dalam upaya menyelesaikan permasalahan yang mungkin timbul dalam diskusi yang berlangsung secara lebih interaktif dan menyenangkan, (2) siswa lebih mampu mengahargai pendapat dan pertanyaan dari siswa lain ketika proses diskusi, (3) terjadi transfer pengetahuan yang bermakna antar siswa, (4) kegiatan pembelajaran yang menyenangkan membuat siswa siswa lebih aktif dan terlibat secara langsung selama proses pembelajaran, dan (5) melatih siswa untuk berkomunikasi dan menyampaikan pendapat atau materi kepada siswa lain.

Penelitian yang telah dilakukan juga di temui beberapa kelemahan dalam model ini yaitu, (1) pemilihan ketua kelompok yang dilakukan sendiri oleh siswa yang kurang dalam menyampaikan informasi kepada kelompok membuat hambatan bagi anggota lain untuk memahami materi yang telah dijelaskan oleh guru melalui ketua kelompok, (2) pertanyaan yang dibuat oleh kelompok ada yang berasal dari pertanyaan yang ada di buku atau pun internet, sehingga bukan murni dari hasil pemikiran siswa.

\section{KESIMPULAN DAN SARAN}

\section{Kesimpulan}

Berdasarkan analisis data dan pembahasan yang telah diuraikan pada bab sebelumnya, maka dapat disimpulkan bahwa ada pengaruh model pembelajaran
Snowball Throwing terhadap minat belajar geografi siswa kelas XI IIS SMA Negeri 1 Tumpang.

\section{Saran}

Merujuk dari hasil penelitian yang telah diperoleh dan pembahasan yang telah diuraikan, ada beberapa hal yang perlu ditindak lanjuti, yaitu:

Dalam penelitian ini telah diperoleh bahwa penggunaan model pembelajaran Snowball Throwing mempunyai pengaruh yang signifikan terhadap minat belajar siswa. Dengan demikian Guru dianjurkan untuk menerapkan berbagai model ketika melaksanakan proses pembelajaran di sekolah, salah satunya adalah model pembelajaran Snowball Throwing karena layak dan mampu untuk meningkatkan minat belajar siswa.

Penelitian ini telah membuktikan bahwa penggunaan model pembelajaran Snowball Throwing mempunyai pengaruh yang signifikan terhadap minat belajar siswa. Dalam penelitian ini pengaruh model pembelajaran Snowball Throwing hanya pada minat belajar siswa, mengingat manfaat dalam penggunaan model pembelajaran sangat banyak maka Peneliti selanjutnya perlu melakukan penelitian tentang model pembelajaran Snowball Throwing pada materi lain dan mengukur kemampuan lainnya misalnya kemampuan dalam ranah kognitif atau ranah psikomotorik. Selain itu perlu melakukan perbaikan dalam organisasi waktu agar waktu yang digunakan ketika proses pembelajaran lebih efisien.

\section{DAFTAR PUSTAKA}


Amalia, N. K. 2015. Pengaruh Model Pembelajaran Kooperatif Snowball Throwing dan Siklus Belajar 5E Terhadap Minat Belajar dan Hasil Belajar Kognitif IPA Siswa Kelas VIII SMPN di Malang. Skripsi tidak diterbitkan. Malang: Universitas Negeri Malang.

Gie. 1998. Cara Belajar yang Efektif. Yogyakarta: PUBIB

Hamdayana, Jumanta. 2014. Model dan Metode Pembelajaran Kreatif dan Berkarakter. Bogor: Penerbit Ghalia Indonesia

Purwanto, Edy. 2013. Setrategi Pembelajaran Bidang Studi Geografi. Malang: Penerbit Universitas Negeri Malang.

Schunk, dkk. 2012. Motivasi dalam Pendidikan, Teori, Penelitian, dan Aplikasi. Jakarta: PT Indeks
Slameto. 2010. Belajar dan Faktor-faktor yang Mempengaruhinya. Jakarta: Rineka Cipta

Sudaryono, dkk. 2013. Pengembangan Instrumen Penelitrian Pendidikan. Yogyakarta: Graha Ilmu.

Wahyuningsih, A. T. 2013. Pengaruh Model Pembelajaran Snowball Throwing terhadap Hasil Belajar pada Pokok Bahasan Pedosfer Siswa Kelas X di SMAN 1 Pule Kabupaten Trenggalek. Skripsi tidak diterbitkan. Malang: Universitas Negeri Malang.

Yohana, Ratih. 2011. Penerapan Model Snowball Throwing untuk Meningkatkan Aktivitas dan Hasil Belajar IPS Siswa Kelas VII A SMP Muhammadiyah 4 Singosari Kabupaten Malang. Skripsi tidak diterbitkan. Malang: Universitas Negeri Malang. 